\title{
Article
}

\section{Physicians' views and experiences of discussing weight management within routine clinical consultations: A thematic synthesis}

Dewhurst, Anne, Peters, Sarah, Devereux-Fitzgerald, Angela and Hart, Jo

Available at http://clok.uclan.ac.uk/29265/

Dewhurst, Anne ORCID: 0000-0001-9726-6363, Peters, Sarah, DevereuxFitzgerald, Angela and Hart, Jo (2017) Physicians' views and experiences of discussing weight management within routine clinical consultations: $A$ thematic synthesis. Patient Education and Counseling, 100 (5). pp. 897-908. ISSN 0738-3991

It is advisable to refer to the publisher's version if you intend to cite from the work. http://dx.doi.org/10.1016/j.pec.2016.12.017

For more information about UCLan's research in this area go to http://www.uclan.ac.uk/researchgroups/ and search for <name of research Group>.

For information about Research generally at UCLan please go to http://www.uclan.ac.uk/research/

All outputs in CLoK are protected by Intellectual Property Rights law, including Copyright law. Copyright, IPR and Moral Rights for the works on this site are retained by the individual authors and/or other copyright owners. Terms and conditions for use of this material are defined in the policies page. 
Physicians' views and experiences of discussing weight management within routine clinical consultations: a thematic synthesis.

Anne Dewhurst ${ }^{\mathrm{a}^{*}}$, Sarah Peters ${ }^{\mathrm{b}}$, Angela Devereux-Fitzgerald ${ }^{\mathrm{c}}$, Jo Hart . $^{\mathrm{d}}$.

${ }^{\text {a }}$ School of Psychological Sciences, University of Manchester, Manchester UK

${ }^{\mathrm{d}}$ Manchester Medical School, University of Manchester, Manchester, UK

\section{Corresponding author}

Anne Dewhurst

School of Psychological Sciences, The Manchester Centre for Health Psychology

University of Manchester

Manchester, M13 9PL

UK

Tel +44 1613061750

Email: anne.dewhurst@manchester.ac.uk 


\section{Abstract}

Objective: To systematically search and synthesise qualitative studies of physicians' views and experiences of discussing weight management within a routine consultation.

Methods: A systematic search of four electronic databases identified 11,169 articles of which 16 studies met inclusion criteria. Quality was appraised using the Critical Appraisal Skills Programme tool and a thematic synthesis conducted of extracted data.

Results: Four analytical themes were found: (1) physicians' pessimism about patients' weight loss success (2) physicians' feel hopeless and frustrated (3) the dual nature of the physician-patient relationship (4) who should take responsibility for weight management.

Conclusion: Despite clinical recommendations barriers remain during consultations between physicians and patients about weight management. Many of these barriers are potentially modifiable. Practice implications: Improving training, providing clearer guidelines and placing a greater emphasis on collaboration within and between clinicians will help reduce barriers for both physicians and patients. In particular, there is an urgent need for more specialised training for physicians about weight management to promote knowledge and skills in behaviour change techniques and ways to broach sensitive topics without damaging patient relationships.

Key words: weight management, patient-physician relationship, meta synthesis 


\section{Introduction}

By 2030 nearly half the world's adult population will be either overweight or obese [1]. In a significant number of European countries a fifth of adults are obese [2]. The UK has the second highest prevalence of obesity in the world [3] and by 2030, 11 million more adults are estimated to become obese [4]. Given the close association between obesity and many comorbid conditions (e.g. type 2 diabetes, cardiovascular diseases, and some forms of cancer [4]), the economic implications are substantial: by 2050 [6] and the global economic cost of obesity is an estimated 2 trillion [1].

Family physicians have access to wide segments of the population [13] offering key information [14] and are a trusted source of advice [15] so are well placed to address weight $[10,16]$. The National Institute for Health and Care Excellence (NICE) recognise the important role health care professionals (HCPs) can play in preventing disease $[9,10,11,3]$ seeing obese patients before they develop further complications [12] and recommend they explore barriers to weight management during routine consultations [8].

HCPs also acknowledge their role regarding weight management $[17,18,19]$ providing increasing levels of support to obese patients [18,20]. Furthermore, patients value receiving advice from physicians $[21,22,16]$ with research suggesting that obese patients value a positive relationship with their physician and cite this as a key motivator to access care [23]. More specifically, patients would like increased input from their physicians about weight management [24], particularly when conversations are embedded in existing health problems [25]. Advice received can increase motivation [26] and accelerate weight loss [27]. However, less than $40 \%$ of obese patients receive 
weight loss counselling [28,29] and fewer than $1 \%$ of physician consultations focus on weight management [16].

Barriers to giving weight management advice reported by physicians include insufficient confidence, knowledge and skills [30] and lack of time [30,31,32]. Additional factors include limited access to dieticians and nutritionists, [10] fear of breaking the doctor-patient relationship, [33] suboptimal training, [33, 26, 34] failure to acknowledge responsibility, [27] limited medical options for patients [35] and finding weight management unrewarding [36]. All suggest potential for improvement [30, $32,33]$.

Thus as obesity levels rise, physicians still report significant barriers to weight management with some research suggesting decreasing levels of weight loss advice [37]. There is therefore a pressing need to gain a deeper understanding of the factors influencing weight management counselling during clinical consultations [38].

A recent review and meta-synthesis focused on the quantitative literature about communication about weight management [118]. Qualitative research is ideally suited to exploring the realities of routine clinical consultations [9]. Furthermore, physicians may hold more complex views than have been previously identified using quantitative methods [40]. As the literature on qualitative explorations of these views grows, there is a need to synthesise it to identify common findings and potentially new insights and directions for further research. Therefore, the aim of this thematic synthesis is to explore qualitative research pertaining to family physicians' views and experiences of discussing weight management within routine clinical consultations. 


\section{Methods}

In health care, quantitative studies are sometimes unable to uncover data captured by qualitative designs. Thematic synthesis provides knowledge essential to evidence based research [41] and ensures the development of analytical and descriptive themes that exceed the primary studies [42] as well as being a valuable source of research for public health $[43,44,45,41]$.

The study comprised four stages: (1) a systematic search of key databases, (2) record retrieval and screening for relevance, (3) critical appraisal, (4) thematic synthesis as described by Thomas and Harden (2008). This technique has been widely used by researchers to gain a deeper insight into HCPs' experiences within the health care system $[46,47]$.

\subsection{Formulating the research question}

To establish the synthesis framework, an interpretation of the population/problem of interest, intervention, comparison and outcome (PICO) framework [48] was used to find qualitative studies exploring physicians' views and experiences of discussing weight management within routine consultations (see Table 1). Previous researchers have used this strategy to identify qualitative papers [49,50,51]. Scoping exercises were used to refine search terms. At this stage, for purposes of manageability of data we decided to narrow our search to physicians only. The concluding set of PICO terms used in the search strategy is shown in Table 1. The PICO framework was used to organise the search strategy which was developed following scoping exercises. 
[Table 1 about here]

\subsection{Inclusion and exclusion criteria}

Inclusion criteria were: (i) studies used qualitative methods for recruitment strategies, data generation and analysis [52] (ii) studies elicited physicians' views and experiences of discussing weight management within routine clinical consultations (iii) articles published in English (iv) the study explicitly focused on obesity (v) studies in which fifty per cent of the sample or more are physicians.

\subsection{Data sources and search strategy}

The search terms were combined using the Boolean logic terms "or" and "and". Keywords were truncated and synonyms of key search terms were used to elicit all relevant studies. MeSH explode was used where possible (See Table 1). Keywords were used such as: GP, patient, physician, general practitioner, doctor, exercise and qualitative. The database searches were executed from inception to May 2016 (see Table 2).

[Table 2 about here]

\subsection{Systematic identification of literature}


Four electronic databases were searched: MEDLINE, EMBASE, CINAHL and PsycINFO from inception to May 2016. The search strategy identified 11,169 articles which were imported into an Endnote bibliographic database.

Following both electronic and manual elimination of duplicates abstracts were screened and if potentially relevant, full texts accessed. The initial screening questions were: 'Did it involve qualitative methods of data collection and analysis?' and 'is the research relevant to the synthesis topic?'. Sixteen papers were included in the final synthesis. (see Figure 1).

[Figure 1 about here]

\subsection{Critical appraisal}

Papers were critically appraised for rigour, credibility and relevance using an adapted Critical Appraisal Skills Programme (CASP) checklist [65] which has been used widely in meta-syntheses (e.g. $60,61,62,63,64,65,66]$. Studies were rated using a 3-point scale ('key' $=$ added considerable richness, 'satisfactory' $=$ fulfilled the CASP criteria, and 'unsatisfactory' $=$ failed the CASP criteria and/or did not enrich the analysis [63]. 4 were judged to be 'satisfactory' and 12 'key'. Evidence suggests negligible difference between 'key' and 'satisfactory' papers in terms of contribution to analysis (Malpass et al, 2009), hence study findings were weighted equally in the synthesis. A coauthor (ADF), blind to original scores, rated each paper. One hundred per cent agreement was achieved.

\subsection{The Synthesis Process}


Thematic synthesis [41] is well-established and has been used to review health professionals' perspectives [54]. Data extraction and thematic synthesis was conducted as outlined [41]. All studies were read and reread closely and key information recorded within data extraction forms. Free line-byline coding of the article findings was followed by the development of descriptive themes. The final stage involved the generation of analytical themes. The analysis was led by the first author but all authors regularly met to discuss, refine and agree upon emergent themes.

\section{Results}

\subsection{Description of selected studies}

Across the 16 studies data were provided from $402 \mathrm{HCPs}$ (range 12 to 60 participants), including GPs, nurses and dieticians. Five were based in the USA, 2 in Germany, 1 in Sweden, 1 in Portugal, 1 in the United Arab Emirates, 1 in Australia, 1 in New Zealand and 4 in the UK. All were published in English between 2001 and 2015. Eleven used semi-structured interviews, 1 used in-depth interviews, 3 focus groups and 1 focus group plus semi-structured interviews (see Table 3 for methodological detail). The studies focused on two key areas, firstly, exploring physicians' views and experiences of discussing weight management with overweight/obese patients and secondly physicians' views and experiences of implementing obesity guidelines. A variety of analysis was used and there was both an

under and over reliance on raw data. The researcher participant relationship was only partially explored (see Table 3 for details).

[Table 3 about here] 


\subsection{Thematic Synthesis}

Analytical themes were: physicians' pessimism about patients' weight loss success, physicians' feel hopeless and frustrated, the dual nature of the physician-patient relationship and who should take responsibility for weight management (see figure 2).

[Figure 2 about here]

\section{Physicians' pessimism about patients' weight loss success}

Physicians were pessimistic about weight management viewing it as too difficult for patients to achieve and sustain. Physicians' perceived that patients lacked willpower, found behaviour change challenging and were unaware of the risks of obesity. Furthermore, patients had little nutritional awareness, were untruthful about their diet, made excuses for their weight and were reluctant to accept responsibility for their problem. They found this frustrating, leading to a general malaise to address weight management feeling that success with patients was unlikely.

"very few succeed in losing weight, and even those only lose a little. Lack of success among their patients has also made them less optimistic about their ability to help others in the future" Hansson (2011) [author interpretation]

"anecdotes of success were frequently related with an expression of surprise" Claridge (2014) [author interpretation] 
Physicians used a range of techniques to effect weight management: goal setting, rolling with resistance (a motivational interviewing technique) food diaries and scare tactics. Physicians emphasised 'partnering' and although they encouraged patients to address unrealistic weight loss goals by taking gradual steps both behaviour change and weight loss were a constant challenge [see text box 1].

[Text box 1 includes a selection of quotations from the four analytical themes]

However, physicians recognised that it was a constant battle for patients to sustain motivation and they were unlikely to maintain weight loss and lasting behaviour change:

"I also tell [patients] that [your weight loss plan is] going to work for a few weeks or months, and then you're going to go back to your same old bad old habits. When you fall off the wagon it doesn't mean that you go and eat the half-gallon of ice cream...You have to say, Okay, I fell off the wagon, I'm not a bad person, stop all the negative stuff-tomorrow, you get back on the program" Gudzune (2012) [Primary Care Provider].

This negative reaction from physicians may serve to perpetuate a sense of learned helplessness within patients who find weight management a constant challenge: 
"I just haven't seen it be very successful with very many people .... I mean the reality is [that] you know from everywhere you look weight loss doesn't work very well for most people" Leverence (2007) [Family Physician 2]

\section{Physicians' feel hopeless and frustrated}

Physicians found discussing weight frustrating and prioritised immediate health concerns when patients' presented with comorbidities, thus avoided initiating a discussion about weight. This was due to time constraints or an eagerness to fit the patient's agenda.

Physicians expressed dissatisfaction with the paucity of available and effective medical management options (weight loss drugs or bariatric surgery) leaving them feeling helpless and overwhelmed:

"If they did accept responsibility for a patient's weight, none of the available treatment options were particularly effective', Epstein \& Ogden (2005) [Author interpretation]

"Some felt [bariatric surgery] was a last resort, because of the cost and risks associated with it" Kim et al (2015) [Author interpretation]

Physicians reported encouraging patients to join commercial weight loss programmes and perceived these to somewhat effective. External support, specifically dieticians, was considered but participants perceived insufficient access to such services to meet patient volumes. Where available, physicians preferred a practice-based dietician. 
Physicians reported a lack of joined up approach to weight management by services with poor communication between GPs, Nurses and other HCPs. It was argued that this led to disenfranchised care:

'They also demonstrate some scepticism regarding... referral to dietician or act in collaboration with other specialities was not a common practice'. Teixiera (2015) [author interpretation]

Weight management was perceived as unrewarding work and this negativity affected physicians within their practices and teams. Physicians also reported that weight guidelines lacked clarity, were difficult to implement locally and rarely used, often due to time pressures. Guidelines were sometimes in conflict with physicians' treatment beliefs as some perceived that medical interventions recommended were ineffective.

"Well we certainly saw the SIGN guidelines (on weight management) and were horrified. There were aspects of the SIGN guidelines that we found quite unacceptable, particularly the recommendation to use appetite suppressants" Mercer \& Tessier (2001) [General Practitioner]

Physicians wanted more transparent guidelines, especially information on dietary advice that was non-contradictory and consistent: 
Staff were especially eager for guidelines regarding dietary advice, which at present tended to be vague. Because of the many contradictions, different opinions and extensive debate about what were the most successful diet regimes, staff regarded it as difficult to offer balanced advice to patients Hansson (2011) [author interpretation]

Finally, physicians expressed a desire for increased knowledge and training in motivational interviewing (MI), nutritional awareness, how to address weight management, cognitive behavioural techniques (CBT) and training via short courses and distance learning. Interestingly, physicians who had received prior training in MI were less frustrated with lack of success.

\section{The dual nature of the physician-patient relationship}

Physicians used the strength of their relationship with patients as a foundation for discussions about weight with increased rapport, continuity of care and knowledge of the patient's history enabling effective "partnering'. This allowed them to assess patient's motivation and gain a deeper insight into their world. 'Partnering' was key as weight management was perceived to be a continuous process that shouldn't be tackled within short consultations. A sense of ease and progression within the relationship provided a platform for discussion and proved beneficial.

"Often, they saw that people were non-compliant to advice year after year but then suddenly things started to happen. The importance of encountering the same personnel was stressed by a number of staff" Hansson (2011) (author interpretation). 
Central to the relationship was the use of patient-centred care (PCC). Physicians valued dimensions of PCC such as empathy, sharing positive and negative experiences and an appreciation that patients' needs were physical, psychological and social. Tailoring weight management to meet patients' individual needs and using PCC as a platform was pivotal:

"Both GPs and patients emphasized the value of successful patient-centred communication. When discussing the importance of communication, physicians mentioned trust as well as empathy and respect as essential prerequisites" Heintze (2012) (author interpretation).

Physicians were hesitant to discuss weight as it was considered a sensitive topic and may impair their relationship:

'Several of the barriers... were unique to GPs, who expressed concern that raising the topic of weight conflicted with their desire to maintain a non- judgmental relationship with patients' Blackburn (2015) [Author Interpretation]

To preserve relationships, discussions were delayed until rapport had been established. However, some physicians avoided the topic prioritising conditions that were viewed as easier to treat. Physicians feared negative reactions from patients and disguised the topic of weight using positive framing such as 'healthy lifestyle' rather than 'weight loss'. Physicians used 'hooks' such as measuring body size and then presenting facts to the patient. Physicians perceived these techniques allowed them to address the topic whilst avoiding offence. 
4. Who should take responsibility for weight management?

Weight talk was perceived as only legitimate when it was linked to comorbidities. This also reduced the tension and ambiguity associated with treating obesity alone. In contrast, if obese patients presented in the absence of illness some physicians viewed this as non-medical and hence not their responsibility. The exception was when obesity levels were sufficiently severe.

"Being obese has a whole lot of medical implications...but it's the medical ones that we tend to. We are on safe ground I suppose with medical implications". Claridge et al (2014) [GP 2]

"Overweight and obesity were seen more as conditions that might involve a risk of diabetes or some other disease. If a concomitant disorder was present.. it was important to intervene". Hansson (2011) [author interpretation]

Some physicians did not consider a legitimate medical solution existed for obesity and concurred when patients did not want medical solutions. They believed medication was a temporary solution and the key to success was maintaining behaviour change.

"I am not entirely sure that to medicalise it is the way forward" Mercer \& Tessier (2001)

[General Practitioner] 
Physicians recognised that environmental barriers prevented physical activity and decreased patient motivation and this supported the idea that weight management was outside their remit, and that responsibility lay at a societal not an individual level.

Some physicians referred patients to external weight management services believing managing weight was a societal problem so responsibility lay with external services. These services were more appropriate than 'medicalising the problem' and group based programmes more effective as they encouraged patients to take responsibility. Moreover, these services possessed 'specialised knowledge' that physicians did not have themselves.

Physicians identified cultural barriers such as a paucity of acceptable facilities for women to exercise, social habits revolving around communal meals and the perception that to be thin was to be unhealthy. Challenging these deeply held cultural beliefs was difficult and also outside physicians remit.

However, some physicians were clear they held some responsibility for helping patients manage weight.

“One GP called himself a 'gathering place' (GP2) for all health-related complaints and underlined his responsibility for patients' health" Sonntag (2012) [author interpretation]

In contrast, some suggested that weight management was the patient's responsibility. This resulted in a sense of conflict as they were aware that patients looked to them to take control and solve their weight problem, leaving them disheartened: 
"GPs therefore described the issue of responsibility and although they felt that obesity was ultimately the patient's problem, they felt that patients wanted the doctor to take ownership. This conflict resulted in GPs feeling frustrated with their patients' inability to change their lifestyle" Epstein \& Ogden (2005) [author interpretation]

There were different views as to who, within the primary care team, was responsible for supporting patients in weight management. This was usually delegated to a more junior member of the team. Finally, physicians lacked defined roles resulting in them relinquishing responsibility to other colleagues:

“we very much leave it to the practice nurse. I do not think it is a GP's job to be doing hands on work- it is my responsibility to make sure it has been tackled by someone else" Mercer \& Tessier (2001) [General Practitioner]

\section{Discussion \& conclusion}

\subsection{Discussion}

This review is the first to synthesise literature exploring physicians' views of discussing weight management within consultations and suggests that physicians continue to find weight management challenging. Novel themes were based on 16 studies establishing a robust body of evidence. The four analytical themes indicated that physicians perceive weight management as a difficult task for them and patients, and question who is best placed to address it. They prioritise relationships with their 
patients and perceive this helps to address the topic of weight without offending. Physicians used a variety of behaviour change techniques (BCTs) such as goal setting or encouragement $[29,72]$ when discussing weight and were more confident that these would achieve success with patients as opposed to general advice. However, some still failed to use BCTs [33,35] or used ones with a weak evidence base e.g. fear arousal [76]. Both physicians and patients may benefit from further training in BCTs [77] or in methods such as motivational interviewing (MI). Furthermore, quantitative research proposes that physicians are pessimistic about patient motivation to lose weight, $[78,28,79]$ however, evidence shows that physicians may be underestimating it $[35,14]$. This suggests more effective communication between physicians and patients may increase motivation levels. Finally physicians' perceived that overweight/obese patients were in denial. This is in line with patients' views of their own weight suggesting that patients with a raised BMI often underestimate their own body weight $[80,81]$.

Our analysis supports previous findings that physicians consider weight management unrewarding $[17,82,83,84,36,85]$. Physicians feel they have insufficient management options and are sceptical about their efficacy [83,35]. Physicians feel more confident offering medical solutions which may suggest why they are reticent to address weight [86]. In the absence of other options physicians encouraged patients to use commercial weight management services. Indeed, commercial slimming clubs can be more cost-effective for weight loss than primary care services led by trained staff [87]. Physicians advocated a joined-up approach to weight management. This supports the implementation of a collaborative obesity care model, [88] European Clinical Practice Guidelines, [2] NHS England [89] and the USPSTF [90] recommending clinical pathways for obesity and multidisciplinary teams to deliver weight management. However, guidelines often lacked clarity leading to physicians' 
reluctance to follow them and a lack of confidence in treatment recommendations [91]. Physicians wanted greater nutritional awareness and to learn techniques such as CBT and MI to motivate patients when addressing weight. Similar findings suggest physicians' desire additional training, support and skills in weight management [35,91, 92,93]. Furthermore, Bleich et al (2015) [88] found that nonphysician HCPs also reported suboptimal training in weight management suggesting little progress in this area. Finally, physicians prioritised critical health concerns, especially when they lacked time or responded to the patient's agenda. This may relate to the fact that weight management is a sensitive topic and physicians' fear offending the patient [86].

The synthesis suggests the physician-patient relationship is a bedrock for weight management discussion but may also deter physicians from broaching it for fear of damaging the relationship. Physicians find weight discussions challenging preferring to treat illnesses they perceive as legitimate medical conditions [86]. Unsurprisingly, many physicians used aspects of patient-centred care (PCC) such as empathy and partnership to facilitate discussions. This is in contrast to Cox et al (2011) [91] who found that physicians rarely used PCC during in situ encounters about weight; suggesting that although physicians' expressed a desire to deliver PCC within our synthesis, their perceptions may not be the same as what they actually do. The themes were interlinking for example the desire to preserve the physician-patient relationship linked strongly to physicians' perception that behaviour change was too difficult for patients. Physicians' perceived that weight management was challenging and lengthy and patients needed a solid foundation to maintain change. In addition, physicians use of PCC to facilitate discussions about weight related to their view that behavior change was hard and difficult for patients. Empathy was vital in order to facilitate weight management. Finally, physicians' 
feared damaging the doctor-patient relationship when discussing weight so prioritised critical health problems especially when consultations were time pressured.

The final theme focused on the issue of responsibility. Physicians lack consistency when discussing weight $[94,95,28,96]$ and the belief that weight management is their patients' responsibility may be one cause [35,27]. Insufficient medical options, poor patient motivation and insufficient training were factors. Physicians argued others were better equipped to address weight, however this was typically delegated where possible to others more junior or with less autonomy. That is unsurprising given weight talk was viewed as unrewarding. The findings suggested that physicians fail to view 'obesity alone' as a legitimate medical problem so was therefore not within their remit. This is consistent with research that physicians are more willing to initiate and discuss weight when they 'medicalize' it or when patients present with comorbidities affecting health outcomes $[86,16]$. In addition medical training favours the biomedical model so physicians may feel more comfortable viewing weight as a medical problem [95]. Lastly, some physicians were reticent to take responsibility for weight suggesting that external factors such as family, society and culture were to blame. This supports previous quantitative research that over half of doctors believed the family was an essential influence on weight loss although few involved them in treatment decisions [82]. Furthermore, some physicians' perceived cultural factors as a barrier to change making them less likely to take responsibility for weight management. However, some studies suggest that ethnic minorities are more likely to be counselled about weight [96] and that physicians in certain cultures such as the USA feel more confident about delivering counselling to ethnic minorities.

\subsection{Strengths}


This thematic synthesis is the first to investigate the views of physicians discussing weight within routine consultations. Despite 13 of the 16 studies taking place in Europe and the USA these results are still consistent with physicians' views from other work undertaken on other continents suggesting generalizability $[83,35]$. All studies were of medium and high quality employing a wide range of methodologies adding to the strength of the findings. Our results complement previous quantitative studies that physicians' lack confidence, knowledge and skills when addressing weight [30] are pessimistic about their patients' ability to lose weight $[28,97]$ fear damaging the doctor-patient relationship [86] and are reticent to take responsibility [27, 98].

\subsection{Limitations}

Researchers have argued that identifying qualitative research is challenging $[100,101,102]$ due to poor indexing within electronic databases $[103,43,104,105]$ and the range of research designs among qualitative studies [99]. A move to more detailed abstracts and keywords to aid indexing would help rectify this [106]. To address this we employed extensive scoping searches prior to conducting systematic searches to increase search sensitivity [104]. Finally, although the selection of CASP was based on positive reviews [66] selecting a pertinent appraisal tool and evaluating qualitative work is a subjective task [107]. CASP may place too much importance on procedural aspects of research [56] and ignore the reasoning underpinning theoretical aspects [107] giving a limited model of enquiry [108]. Providing a gold standard measuring tool for all researchers [109] would be beneficial [103]. 


\subsection{Practice implications}

Despite key policy recommendations from NICE [8] the USPSTF [90] and The Dutch College of General Practitioners (NHG) [110] suggesting physicians prioritise weight discussions with overweight/obese individuals; physicians still report significant barriers and are overwhelmed and frustrated. To reduce the barriers between physicians and patients there is a need for greater collaboration. Sharing knowledge and expertise in both primary, secondary and tertiary care would be useful. In addition, further clarification of physicians' roles and responsibilities is advisable as well as the introduction of weight management 'experts' within GP practices or secondary care. Physicians could benefit from training in brief BCTs, deliverable within time-pressured consultations; such as MI [111]. It is evident that physicians view weight management as sensitive thus specialist training for all physicians at both undergraduate and postgraduate level could help. Finally, there is a potential role for behaviour change practitioners within primary and secondary care to take up this work and support existing practitioners. It has been suggested that health psychologists have the relevant skills to fulfil this role and may ease the burden on existing physicians and provide a more cost effective solution [112].

\subsection{Conclusion}

This review suggests that physicians continue to find discussions about weight arduous. Physicians are keen to safeguard the doctor-patient relationship and view the topic of weight as a potential threat to this, employing strategies to balance and preserve it. In addition, physicians perceive that weight management is too difficult for both patients and themselves and that they have insufficient support and expertise from colleagues and adequate treatment options. They also lack appropriate training, 
knowledge or weight management infrastructure to deal with this crisis. Finally, physicians vary in the level of responsibility they accept for weight management. When physicians do accept responsibility this is often due to 'legitimate medical reasons' such as concomitant disorders that they feel obligated to address.

\section{Ethical approval}

Not applicable.

\section{Conflict of Interest}

No conflict of interest was declared

\section{Funding}

The first author was funded by the Medical Research Council as part of a doctoral studentship. 


\section{References}

[1] Dobbs, R., Sawers, C., Thompson, F., Manyika, J., Woetzel, J. R., Child, P., ... \& Spatharou, A. (2014). Overcoming obesity: An initial economic analysis. McKinsey Global Institute.

[2] James, W. P. T. (2008). The epidemiology of obesity: the size of the problem. Journal of internal medicine, 263(4), 336-352.

[3] Royal College of Physicians. (2013) Action on obesity: comprehensive care for all. Report of a working party. London: RCP.

[4] Wang, C.Y., McPherson, K., Marsh, T., Gortmaker, S.L., Brown, M. (2011). Health and economic burden of the projected obesity trends in the USA and the UK. Lancet, 378, 815-825.

[5]World Health Organisation (WHO) (2000) Obesity: Preventing and Managing the Global Epidemic, Geneva: WHO.

[6] Jebb, S., Kopelman, P., McPherson, K., Thomas, S., Mardell, J., \& Parry, V. (2007). Tackling Obesities: Future Choices: Project Report. Department of Innovation Universities and Skills.

[7] Mercer, S. (2009). How useful are clinical guidelines for the management of obesity in general practice?. British Journal of General Practice, 59(568), 863-868.

[8] National Institute for Health and Care Excellence (2014) Weight management: lifestyle services for overweight or obese adults. https://www.nice.org.uk/guidance/ph53/chapter/1-recommendations 
(accessed 30 June 2014)

[9] Epstein L, Ogden J. (2005) A qualitative study of GPs' views of treating obesity. British Journal Of General Practice, 55, 750-754.

[10] Maryon-Davis, A. (2005). Weight management in primary care: how can it be made more effective?. Proceedings of the Nutrition Society, 64(01), 97-103.

[11] Nolan, C., Deehan, A., Wylie, A., \& Jones, R. (2012). Practice nurses and obesity: professional and practice-based factors affecting role adequacy and role legitimacy. Primary health care research \& development, 13(04), 353-363.

[12] Jarvis, S. (2006). Obesity and the overworked GP. British Journal of General Practice, 56(530), $654-655$.

[13] Bowerman, S., Bellman, M., Saltsman, P., Garvey, D., Pimstone, K., Skootsky, S., ... \& Heber, D. (2001). Implementation of a primary care physician network obesity management program. Obesity research, 9(S11), 321S-325S.

[14] Heintze, C., Metz, U., Hahn, D., Niewöhner, J., Schwantes, U., Wiesner, J., \& Braun, V. (2010). Counseling overweight in primary care: an analysis of patient-physician encounters. Patient education and counseling, 80(1), 71-75.

[15] Steptoe, A., Rink, E., \& Kerry, S. (2000). Psychosocial predictors of changes in physical activity 
in overweight sedentary adults following counseling in primary care. Preventive medicine, 31(2), 183-194.

[16] Tham, M., \& Young, D. (2008). The role of the General Practitioner in weight management in primary care-a cross sectional study in General Practice. BMC Family Practice, 9(1), 66.

[17] Bocquier A, Verger P, Basdevant A, et al. Overweight and obesity: knowledge, attitudes, and practices of general practitioners in France. Obesity Research 2005;13:787-95

[18] Brown, I., \& Thompson, J. (2007). Primary care nurses' attitudes, beliefs and own body size in relation to obesity management. Journal of advanced nursing, 60(5), 535-543.

[19] Lazarou, C., \& Kouta, C. (2010). The role of nurses in the prevention and management of obesity. British Journal of Nursing, 19(10), 641.

[20] Bourn, J. (2001). Tackling obesity in England. The Stationery Office, London, UK.

[21] Fontaine, K. R., Haaz, S., \& Bartlett, S. J. (2007). Are overweight and obese adults with arthritis being advised to lose weight?. JCR: Journal of Clinical Rheumatology, 13(1), 12-15.

[22] Hart, J., Yelland, S., Mallinson, A., Hussain, Z., \& Peters, S. (2015). When is it ok to tell patients they are overweight? General public's views of the role of doctors in supporting patients' dieting and weight management. Journal of Health Psychology, 1359105315571974. 
[23] Buxton, B. K., \& Snethen, J. (2013). Obese women's perceptions and experiences of healthcare and primary care providers: A phenomenological study. Nursing research, 62(4), 252-259.

[24] Ashenden, R., Silagy, C., \& Weller, D. (1997). A systematic review of the effectiveness of promoting lifestyle change in general practice. Family practice, 14(2), 160-176.

[25] Hart, J., Yelland, S., Mallinson, A., Hussain, Z., \& Peters, S. (2015). When is it ok to tell patients they are overweight? General public's views of the role of doctors in supporting patients' dieting and weight management. Journal of health psychology, 1359105315571974.

[26] Ulbricht, S., Meyer, C., Schumann, A., Rumpf, H. J., Hapke, U., \& John, U. (2006). Provision of smoking cessation counseling by general practitioners assisted by training and screening procedure. Patient education and counseling, 63(1), 232-238.

[27] Hash, R. B., Munna, R.K, Vogel, R.L., Bason, J.J. (2003). Does Physician Weight Affect Perception of Health Advice? Preventive Medicine 36,1, 41-44.

[28] Galuska, D.A, Will, J.C., Serdula, M.K., Ford, E.S. (1999) Are health care professionals advising obese patients to lose weight? Journal of the American Medical Association, 282, 1576-8.

[29] Gudzune, K. A., Clark, J. M., Appel, L. J., \& Bennett, W. L. (2012). Primary care providers' communication with patients during weight counseling: A focus group study. Patient education and counseling, 89(1), 152-157. 
[30] Huang, J., Yu, H., Marin, E., Brock, S., Carden, D., \& Davis, T. (2004). Physicians' weight loss counseling in two public hospital primary care clinics. Academic Medicine, 79(2), 156-161.

[31] Kushner, R. F.(1995) Barriers to providing nutrition counseling by physicians: a survey of primary care practitioners. Preventive Medicine, 24, 546-52.

[32] Noordman, J., Verhaak, P., Van Dulmen, S. (2010) Discussing patient's lifestyle choices in the consulting room: analysis of GP-patient consultations between 1975 and 2008. BMC Family Practice, $11,87$.

[33] Chisholm, A., Hart, J., Lam, V., Peters, S. (2012). Current challenges of behavior change talk for medical professionals and trainees. Patient Education and Counseling 87, 3, 389-394.

[34] Vogt, F. Hall, S. Marteau, T.M. (2007). General practitioners' beliefs about effectiveness and intentions to recommend smoking cessation services: qualitative and quantitative studies. $B M C$ Family Practice, 8, 39.

[35] Claridge, R., Gray, L., Stubbe, M., Macdonald, L., Tester, R., \& Dowell, A. C. (2014). General practitioner opinion of weight management interventions in New Zealand. J Prim, 6(3), 212-20.

[36] Jackson, S. E., Wardle, J., Johnson, F., Finer, N., \& Beeken, R. J. (2013). The impact of a health professional recommendation on weight loss attempts in overweight and obese British adults: a crosssectional analysis. BMJ open, 3(11), e003693. 
[37] Abid, A., Galuska, D., Khan, L. K., Gillespie, C., Ford, E. S., \& Serdula, M. K. (2005). Are healthcare professionals advising obese patients to lose weight? A trend analysis. MedGenMed: Medscape general medicine, 7(4), 10-10.

[38] Leverence, R.R., Williams, R.L., Sussman, A., Crabtree, B.F. (2007) Obesity counseling and guidelines in primary care: a qualitative study. American Journal of Preventive Medicine, 32, 334-9.

[39] Scott, K.M., McGee, M.A., Wells, E., Oakley Browne, M.A. (2008). Obesity and mental disorders in the adult general population. Journal of Psychosomatic Research, 64, 1, 97-105.

[40] Hansson, L. M., Rasmussen, F., Ahlstrom, G.I. (2011). General practitioners' and district nurses' conceptions of the encounter with obese patients in primary health care. BMC Family Practice 12, 7.

[41] Thomas, J., \& Harden, A. (2008). Methods for the thematic synthesis of qualitative research in systematic reviews. BMC medical research methodology, 8(1), 45.

[42] Sutanto, B., Singh- Grewal, D., McNeil, H. P., O'Neill, S., Craig, J. C., Jones, J., \& Tong, A. (2013). Experiences and perspectives of adults living with systemic lupus erythematosus: thematic synthesis of qualitative studies. Arthritis care \& research, 65(11), 1752-1765.

[43] Joseph-Williams, N., Elwyn, G., \& Edwards, A. (2014). Knowledge is not power for patients: a systematic review and thematic synthesis of patient-reported barriers and facilitators to shared decision making. Patient education and counseling, 94(3), 291-309. 
[44] Neely, E., Walton, M., \& Stephens, C. (2014). Young people's food practices and social relationships. A thematic synthesis. Appetite, 82, 50-60.

[45] Papadopoulou, C., Johnston, B., \& Themessl-Huber, M. (2013). The experience of acute leukaemia in adult patients: A qualitative thematic synthesis. European Journal of Oncology Nursing, 17(5), 640-648.

[46] Fleming, A., Bradley, C., Cullinan, S., \& Byrne, S. (2015). Antibiotic Prescribing in Long-Term Care Facilities: A Meta-synthesis of Qualitative Research. Drugs \& aging, 32(4), 295-303.

[47] García-Escamilla, E., Rodríguez-Martín, B., \& Martínez-Vizcaíno, V. (2015). Integration of acupuncture into conventional medicine from health professionals' perspective: A thematic synthesis of qualitative studies. Health:, 1363459315574116.

[48] Booth, A., (2008). Using Evidence in Practice: Unpacking your literature search toolbox: on search styles and tactics. Health Information and Libraries Journal, 25, 313-317.

[49] Cooke, A., Mills, T.A., Lavender, T. (2010) 'Informed and uninformed decision making'Women's reasoning, experiences and perceptions with regard to advanced maternal age and delayed childbearing: A meta-synthesis. International Journal of Nursing Studies, 47, 1317-1329.

[50] Smith, D. E., \& Lavender, T. (2011). The maternity experience for women with a body mass index $>30 \mathrm{~kg} / \mathrm{m} 2$ : a meta-synthesis. BJOG: An International Journal of Obstetrics and Gynaecology, 
DOI: 10.1111/j.1471-0528.2011.02924.x.

[51] Stergiou-Kita, M., Rappolt, S., Dawson, D. (2012) Towards developing a guideline for vocational evaluation following traumatic brain injury: the qualitative synthesis of clients' perspectives. Disability and Rehabilitation, 34, 3, 179-188.

[52] Borg-Xuereb, C., Shaw, R.L., Lane, D.A. (2012). Patients' and health professionals' views and experiences of atrial fibrillation and oral-anticoagulant therapy: A qualitative meta-synthesis. Patient Education and Counseling, 88, 330-337.

[53] Public Health Resource Unit. (1998). Critical appraisal skills programme (CASP). Available from. <http://www.york.ac.uk/inst/crd/ report4.htm>.

[54] Satink, T., Cup, E. H., Ilott, I., Prins, J., de Swart, B. J., \& Nijhuis-van der Sanden, M. W. (2013). Patients' views on the impact of stroke on their roles and self: a thematic synthesis of qualitative studies. Archives of physical medicine and rehabilitation, 94(6), 1171-1183.

[55] BSA Medical Sociological Group (1996) Criteria for the evaluation of qualitative research papers. Medical Sociology News, 22, 68-71.

[56] Dixon-Woods, M., Sutton, A., Shaw, R., Miller, T., Smith, J., Young, B., ... \& Jones, D. (2007). Appraising qualitative research for inclusion in systematic reviews: a quantitative and qualitative comparison of three methods. Journal of health services research \& policy, 12(1), 42-47.

[57] Popay, J., Rogers, A., Williams, G. (1998). Rationale and standards for the systematic review of 
qualitative literature in health services research. Qualitative Health Research, 8, 3, 341-351.

[58] The Joanna Briggs Institute, 2008. Joanna Briggs Institute Reviewers' Manual, 2008 ed. The Joanna Briggs Institute, Adelaide, Australia.

[59]Walsh, D. Downe, S.(2006). Appraising the quality of qualitative research. Midwifery 22, 10819.

[60] Campbell, R., Pound, P., Pope, C., Britten, N., Pill, R., Morgan, M., Donovan, J. (2003).

Evaluating meta-ethnography: a synthesis of qualitative research on lay experiences of diabetes and diabetes care. Social Science \& Medicine, 56, 671-684.

[61] Carlsen,B., Glenton, C., Pope, C. (2007). Thou shalt versus thou shalt not: a meta-synthesis of GPs' attitudes to clinical practice guidelines. British Journal of General Practice. 57, 971-978.

[62] Feder, G.S, Hutson, M., Ramsay, J., Taket, A. R. (2006). Women exposed to intimate partner violence: Expectations and experiences when they encounter health care professionals: A metaanalysis of qualitative studies. Archives of Internal Medicine, 166, 1, 22-37.

[63] Malpass A, Shaw A, Sharp D, Walter F, Feder G, Ridd M, Kessler, D. (2009). "Medication career" or "Moral career"? The two sides of managing antidepressants: a meta-ethnography of patients' experience of antidepressants. Social Science \& Medicine, 68, 154-68.

[64] Pound, P., Britten, N., Morgan, M., Yardley, L., Pope, C., Daker-White, G., Campbell, R. 
(2005). Resisting medicines: a synthesis of qualitative studies of medicine taking. Social Science \& Medicine, 61, 133-155.

[65] Taylor, C. A., Shaw, R. L., Dale, J., \& French, D. P. (2011). Enhancing delivery of health behaviour change interventions in primary care: a meta-synthesis of views and experiences of primary care nurses. Patient education and counseling, 85(2), 315-322.

[66] Angus,J.E., Lombardo, A.P., Lowndes,R.H., Cechetto, N., Ahmad, F., and Bierman, A.S. (2012). Beyond Barriers in Studying Disparities in Women's Access to Health Services in Ontario, Canada: A Qualitative Metasynthesis. Qualitative Health Research, 23, 4, 476-494.

[67] Alexander, Stewart C., Truls Østbye, Kathryn I. Pollak, Margaret Gradison, Lori A. Bastian, and Rebecca J. Namenek Brouwer. "Physicians' beliefs about discussing obesity: results from focus groups." American Journal of Health Promotion 21, no. 6 (2007): 498-500.

[68] Ali, Habiba I., Roos M. Bernsen, and Latifa M. Baynouna. "Barriers to weight management among Emirati women: a qualitative investigation of health professionals' perspectives." International quarterly of community health education 29, no. 2 (2009): 143-159.

[69] Derksen, R. E., W. J. Brink-Melis, M. J. Westerman, J. J. M. ten Dam, J. C. Seidell, and T. L. S. Visscher. "A local consensus process making use of focus groups to enhance the implementation of a national integrated health care standard on obesity care." Family practice 29, no. suppl 1 (2012): i177-i184. 
[70] Gunther, Stephen, Fenglin Guo, Paul Sinfield, Stephen Rogers, and Richard Baker. "Barriers and enablers to managing obesity in general practice: a practical approach for use in implementation activities." Quality in primary care 20, no. 2 (2012): 93-103.

[71] Heintze, Christoph, Ulrike Sonntag, Anna Brinck, Mania Huppertz, Jörg Niewöhner, Julia Wiesner, and Vittoria Braun. "A qualitative study on patients' and physicians' visions for the future management of overweight or obesity." Family practice 29, no. 1 (2012): 103-109.

[72] Yan, Marcia G. Ory, Chanam Lee, Suojin Wang, Jairus Pulczinksi, and Samuel N. Forjuoh. "Walking and Neighborhood Environments for Obese and Overweight Patients." Family medicine 44, no. 5 (2012): 336-41.

[73] Leverence, Robert R., Robert L. Williams, Andrew Sussman, Benjamin F. Crabtree, and RIOS Net Clinicians. "Obesity counseling and guidelines in primary care: a qualitative study." American journal of preventive medicine 32, no. 4 (2007): 334-339.

[74] Mercer, S. W., and S. Tessier. "A qualitative study of general practitioners' and practice nurses' attitudes to obesity management in primary care." Health bulletin 59, no. 4 (2001): 248-253.

[75] Sonntag, U., Brink, A., Renneberg, B., Braun, V., \& Heintze, C. (2012). GPs' attitudes, objectives and barriers in counselling for obesity - a qualitative study. The European journal of general practice, 18(1), 9-14. 
[76] Kok, G., Bartholomew, L. K., Parcel, G. S., Gottlieb, N. H., \& Fernández, M. E. (2014). Finding theory- and evidence- based alternatives to fear appeals: Intervention Mapping. International journal of psychology, 49(2), 98-107.

[77] Peters, S., Bird, L., Ashraf, H., Ahmed, S., McNamee, P., Ng, C., \& Hart, J. (2013). Medical undergraduates' use of behaviour change talk: the example of facilitating weight management. $B M C$ medical education, 13(1), 7.

[78] Befort, C.A., Greiner , K.A., Hall, S., (2006) Weight- related perceptions among patients and physicians: how well do physicians judge patients' motivation to lose weight? Journal of General Internal Medicine, 21,1086-1090.

[79] Visser, F., Hiddink, G., Kolen, M., Van Binsbergen, J., Tobi, H., Van Woerkum, C. (2008). Longitudinal changes in GPs' task perceptions, self-efficacy, barriers and practices of nutrition education and treatment of overweight. Family practice 25, 105-111.[

80] Gregory, C.O.; Blanck, H.M.; Gillespie, C.; Maynard, L.; Serdula, M.K. Health perceptions and demographic characteristics associated with underassessment of body weight. Obesity 2008, 16, 979986.

[81] Kuchler, F.; Variyam, J.N. Mistakes were made: misperception as a barrier to reducing overweight. Int. J. Obes. Relat. Metab. Disord. 2003, 27, 856-861.

[82] Cade, J., \& O'Connell, S. (1991). Management of weight problems and obesity: knowledge, attitudes and current practice of general practitioners. British Journal of General Practice, 41(345), $147-150$. 
[83] Campbell K, Engel H, Timperio A, et al. (2000). Obesity management: Australian general practitioners' attitudes and practices. Obesity Research 8: 459-66.

[84] Frank A. (1993). Futility and avoidance. Medical professionals in the treatment of obesity. JAMA 269. 2132-3.

[85] Ruelaz, A.R., Diefenbach, P., Simon,B., Lanto, A., Arterburn, D., Shekelle, P.G. (2007) Perceived barriers to weight management in primary care-perspectives of patients and providers. Journal of General Internal Medicine, 22, 518-22.

[86] Scott, J.G., Cohen, D., Di Cicco-Bloom, B., Orzano, A.J., Gregory, P., Flocke, S.A., Maxwell, L., Crabtree, B. (2004) Speaking of weight: how patients and primary care clinicians initiate weight loss counseling. Preventive Medicine, 8, 6, 819-827.

[87] Jolly, K., Lewis, A.,Beach, J., Denley, J., ADab, P., Deeks, J., Daley, A., Aveyard, P. (2011). Comparison of range of commercial or primary care led weight reduction programmes with minimal intervention control for weight loss in obesity: Lighten Up randomised controlled trial. British Medical Journal, 343.

[88] Bleich, S. N., Bandara, S., Bennett, W. L., Cooper, L. A., \& Gudzune, K. A. (2015). US Health Professionals' Views on Obesity Care, Training, and Self-Efficacy. American journal of preventive medicine, 48(4), 411-418. 
[89] NHS England (2014a) Joined up Clinical Pathways for Obesity: Report of the Working Group. NHS England, London. Available at: http://bit.ly/RNNm7S (accessed 23.02.15)

[90] U.S. Preventive Services Task Force. (2003) Screening for obesity in adults: recommendations and rationale. Ann Intern Med. 139(11): 930-932.

[91] Cox, M. E., Yancy, W. S., Coffman, C. J., Østbye, T., Tulsky, J. A., Alexander, S. C., ... \& Pollak, K. I. (2011). Effects of counseling techniques on patients' weight-related attitudes and behaviors in a primary care clinic. Patient education and counseling, 85(3), 363-368.

[92] Forman-Hoffman, V., Little, A., Wahls, T. (2006). Barriers to obesity management: a pilot study of primary care clinicians. BMC Family Practice 7, 35.

[93] Mold, F., \& Forbes, A. (2011). Patients' and professionals' experiences and perspectives of obesity in health- care settings: a synthesis of current research. Health Expectations, 16(2), 119-142.

[94] Bleich, S. N., Huizinga, M. M., Beach, M. C., \& Cooper, L. A. (2010). Patient use of weightmanagement activities: A comparison of patient and physician assessments. Patient education and counseling, 79(3), 344-350.

[95] Foster G. D., Wadden, T.A., Makris, A.P., Davidson, D., Sanderson, R.S., Allison, D.B. (2003) Primary care physicians' attitudes about obesity and its treatment. Obesity Research 11, 1168-77. 
[96] Ma, J., Urizar, G.G. Tseday Alehegn, M.A., Randall, S., Stafford, M.D. (2004). Diet and physical activity counseling during ambulatory care visits in the United States. Preventive Medicine $39,4,815-822$.

[97] Timmerman, G.M., Reifsnider, E., Allan, J.D. (2000) Weight management practices among primary care providers. Journal of the American Academy of Nurse Practitioners, 12, 4, 113-116.

[98] Bleich, S.N, Simon, A.E, Cooper, L.A. (2011) Impact of patient-doctor race concordance on rates of weight-related counseling in visits by Black and White obese individuals. Obesity, 20, 562570.

[99] Anderson, V. R., Jason, L. A., Hlavaty, L. E., Porter, N., \& Cudia, J. (2012). A review and metasynthesis of qualitative studies on myalgic encephalomyelitis/chronic fatigue syndrome. Patient education and counseling, 86(2), 147-155.

[100] Evans, D. (2002). Database searches for qualitative research. Journal of the Medical Library Association, 90(3), 290.

[101] Ring, N. A., Ritchie, K., Mandava, L., \& Jepson, R. (2011). A guide to synthesising qualitative research for researchers undertaking health technology assessments and systematic reviews.

[102] Taylor, C. A., Shaw, R. L., Dale, J., \& French, D. P. (2011). Enhancing delivery of health behaviour change interventions in primary care: a meta-synthesis of views and experiences of primary care nurses. Patient education and counseling, 85(2), 315-322. 
[103] Dixon-Woods M, Fitzpatrick R, Roberts K. (2001) Including qualitative research in systematic reviews: opportunities and problems. J Eval Clin Pract 7: 125-33.

[104] Pearson, M., Moxham, T., \& Ashton, K. (2011). Effectiveness of search strategies for qualitative research about barriers and facilitators of program delivery. Evaluation \& the health professions, 34(3), 297-308.

[105] Shaw RL, Booth A, Sutton AJ, Miller T, Smith JA, Young B, et al. (2004) Finding qualitative research: an evaluation of search strategies. BMC Med Res Methodol 4:1-5.

[106] Atkins, S., Lewin, S., Smith, H., Engel, M., Fretheim, A., \& Volmink, J. (2008). Conducting a meta-ethnography of qualitative literature: lessons learnt. BMC medical research methodology, 8(1), 21.

[107] Newton, B. J., Rothlingova, Z., Gutteridge, R., LeMarchand, K., \& Raphael, J. H. (2011). No room for reflexivity? Critical reflections following a systematic review of qualitative research. Journal of health psychology, 1359105311427615.

[108] Denzin, N. K. (2009). The elephant in the living room: or extending the conversation about the politics of evidence. Qualitative research, 9(2), 139-160.

[109] Katrak, P., Bialocerkowski, A. E., Massy-Westropp, N., Kumar, V. S., \& Grimmer, K. A. (2004). A systematic review of the content of critical appraisal tools. BMC Medical Research Methodology, 4(1), 22. 
[110] Van Binsbergen JJ, Langens FNM, Dapper ALM et al. (2010) NHG Standaard Obesitas. Huisarts en Wetenschap 53: 609-25.

[111] Martins, R. K., \& McNeil, D. W. (2009). Review of motivational interviewing in promoting health behaviors. Clinical psychology review, 29(4), 283-293.

[112] Sniehotta, F. F., Simpson, S. A., \& Greaves, C. J. (2014). Weight loss maintenance: An agenda for health psychology. British Journal of Health Psychology, 19 (3), 459-464.

[113] Blackburn, M., Stathi, A., Keogh, E., \& Eccleston, C. (2015). Raising the topic of weight in general practice: perspectives of GPs and primary care nurses. BMJ open, 5(8), e008546.

[114] Kim, K. K., Yeong, L. L., Caterson, I. D., \& Harris, M. F. (2015). Analysis of factors influencing general practitioners' decision to refer obese patients in Australia: a qualitative study. BMC family practice, 16(1), 45.

[115] Schauer, G. L., Woodruff, R. C., Hotz, J., \& Kegler, M. C. (2014). A qualitative inquiry about weight counseling practices in community health centers. Patient education and counseling, 97(1), 82-87.

[116] Teixeira, F. V., Pais-Ribeiro, J. L., \& Maia, A. (2015). A qualitative study of GPs' views towards obesity: are they fighting or giving up? Public health, 129(3), 218-225.

[117] Claridge, R., Gray, L., Stubbe, M., Macdonald, L., Tester, R., \& Dowell, A. C. (2014). General practitioner opinion of weight management interventions in New Zealand. J Prim Health Care, 6(3), 212-20. 
[118] Rose, S. A., Poynter, P. S., Anderson, J. W., Noar, S. M., \& Conigliaro, J. (2013). Physician weight loss advice and patient weight loss behavior change: a literature review and meta-analysis of survey data. International Journal of Obesity, 37(1), 118-128. 


\section{Legends}

Table 1 Terms used to systematically search and synthesise qualitative studies of physicians' views and experiences of discussing weight management within a routine consultation.

\begin{tabular}{|c|c|c|c|}
\hline Population & Intervention & Comparison & Outcome \\
\hline GPs/ patients & Weight management & None & \\
\hline $\begin{array}{l}\text { Physician* } \\
\text { General practit* } \\
\text { GP* } \\
\text { Family pract* } \\
\text { Primary health } \\
\text { care } \\
\text { Doctor* }\end{array}$ & $\begin{array}{l}\text { Obes*, obes* } \\
\text { treatment, obes* } \\
\text { intervention*, obes* } \\
\text { abdominal, obes* } \\
\text { morbid, adipos*, } \\
\text { corpulence, body mass } \\
\text { index, BMI, fat*, } \\
\text { weight*, weight loss, } \\
\text { weight loss goals, } \\
\text { weight gain, weight } \\
\text { related behavio?r, } \\
\text { weight-related } \\
\text { counseling, overweight, } \\
\text { exercise*, diet*, weight } \\
\text { constancy, } \\
\text { weight stability, body } \\
\text { weight, patient weight } \\
\text { management, } \\
\text { physician-directed diet, } \\
\text { weight management, } \\
\text { weight loss } \\
\text { maintenance, adult } \\
\text { obesity, weight related } \\
\text { behavio?rs, weight } \\
\text { management program*, } \\
\text { unsuccessful diet*, } \\
\text { weigh* }\end{array}$ & & $\begin{array}{l}\text { Qualitative Research/ } \\
\text { or qualitative*.mp. } \\
\text { Interviews as topic/ } \\
\text { or exp Focus groups/ } \\
\text { Focus group*.mp. } \\
\text { Interview*.mp }\end{array}$ \\
\hline
\end{tabular}


Table 2

Databases searched

\begin{tabular}{|l|l|l|}
\hline Databases searched & Interface & Coverage \\
\hline PsycINFO & Ovid SP & 1980 to May 2016 \\
MEDLINE & Ovid SP & 1980 to May 2016 \\
EMBASE & Ovid SP & 1980 to May 2016 \\
CINAHL Plus & EBSCO & 1988 to May 2016 \\
\hline
\end{tabular}


Table 3 Description of included articles that were synthesised to capture physicians' views and experiences of discussing weight management $(n=16)$

\begin{tabular}{|c|c|c|c|c|c|c|}
\hline & $\begin{array}{l}\text { Authors \& } \\
\text { country }\end{array}$ & Aim & Participant characteristics & Data collection & Data Analysis & Themes \\
\hline 1 & $\begin{array}{l}\text { Alexander et al } \\
\text { [67] } \\
\text { USA }\end{array}$ & $\begin{array}{l}\text { To examine Physicians' beliefs, } \\
\text { outcome expectancies, and strategies } \\
\text { for addressing weight with patients. }\end{array}$ & $\begin{array}{l}\text { Family physicians } \mathrm{N}=11 \\
\text { Internists } \mathrm{N}=6 \\
\text { Age of participants = not stated } \\
\text { Gender of participants =not stated }\end{array}$ & $\mathrm{N}=2$ Focus groups & $\begin{array}{l}\text { Grounded Theory } \\
\text { (Corbin \& Strauss, } \\
\text { 1993) }\end{array}$ & $\begin{array}{l}\text { 1.Responsibility, } \\
\text { 2.Barriers 3.Target } \\
\text { Populations, 4.Introducing } \\
\text { Topic } \\
\text { 5.Ways to talk about } \\
\text { Obesity }\end{array}$ \\
\hline 2 & $\begin{array}{l}\text { Ali et al [68] } \\
\text { UAE }\end{array}$ & $\begin{array}{l}\text { To explore weight management } \\
\text { barriers for Emirati women and } \\
\text { strategies that can facilitate their } \\
\text { weight management efforts. }\end{array}$ & $\begin{array}{l}\text { Family Medicine } \mathrm{N}=7 \\
\text { General Practitioner (GPs) } \mathrm{N}=8 \\
\text { Dietician } \mathrm{N}=9 \\
\text { Nurse Educator } \mathrm{N}=5 \\
\text { Age of participants=not stated } \\
\text { Gender of participants } \mathrm{N}=29 \text { female }\end{array}$ & $\begin{array}{l}\mathrm{N}=29 \text { In-depth } \\
\text { individual interviews }\end{array}$ & $\begin{array}{l}\text { Grounded Theory } \\
\text { (Cutcliffe, 2004) }\end{array}$ & $\begin{array}{l}\text { 1.Barriers } \\
\text { 2.Motivators \& } \\
\text { Suggestions }\end{array}$ \\
\hline 3 & $\begin{array}{l}\text { Blackburn et al } \\
\text { [113] } \\
\text { UK }\end{array}$ & $\begin{array}{l}\text { To explore general practitioners' } \\
\text { (GPs) and primary care nurses' } \\
\text { perceived barriers to raising the topic } \\
\text { of weight in general practice. }\end{array}$ & $\begin{array}{l}\text { General Practitioners (GPs) } \mathrm{N}=17 \\
\text { Nurses } \mathrm{N}=17 \\
\text { Age }=\text { all between } 32 \text { and } 66 \text { years } \\
\text { GPs modal age range }=30-39 \text { years } \\
\text { Nurses modal age range }=40-49 \text { years } \\
\text { Gender } \\
\text { Nurses } N=17 \text { female } \\
\text { GPs } N=11 \text { female } N=6 \text { male }\end{array}$ & $\begin{array}{l}\mathrm{N}=34 \text { semi-structured } \\
\text { interviews }\end{array}$ & $\begin{array}{l}\text { A deductive } \\
\text { approach to content } \\
\text { analysis to the } \\
\text { Theoretical Domains } \\
\text { Framework (TDF) }\end{array}$ & $\begin{array}{l}\text { 1. Limited understanding } \\
\text { about obesity care } \\
\text { 2.Concern about negative } \\
\text { consequences } 3 \text {. Having } \\
\text { time and resources to raise } \\
\text { a sensitive topic. }\end{array}$ \\
\hline 4 & $\begin{array}{l}\text { Claridge et al } \\
\text { [117] } \\
\text { New Zealand }\end{array}$ & $\begin{array}{l}\text { This study aimed to explore GP } \\
\text { opinion of weight management } \\
\text { interventions in one region of New } \\
\text { Zealand. }\end{array}$ & $\begin{array}{l}\text { General Practitioners } N=12 \\
\text { Age of general practitioners }=N=4 \text { aged } \\
31-39, N=3 \text { aged } 40-60, N=5>60 \\
\text { Gender } N=7 \text { male and } N=5 \text { Female }\end{array}$ & $\begin{array}{l}\mathrm{N}=12 \text { semi-structured } \\
\text { interviews }\end{array}$ & $\begin{array}{l}\text { Inductive thematic } \\
\text { analysis }\end{array}$ & $\begin{array}{l}\text { Five key themes identified: } \\
\text { 1) GP perceptions of what } \\
\text { the GP can do; } 2 \text { ) the roots } \\
\text { of the obesity problem; } 3 \text { ) } \\
\text { why the GP doesn't } \\
\text { succeed; 4) current } \\
\text { primary care } \\
\text { interventions; and 5) } \\
\text { bariatric surgery }\end{array}$ \\
\hline 5 & $\begin{array}{l}\text { Epstein \& Ogden } \\
\text { [9] } \\
\text { UK }\end{array}$ & $\begin{array}{l}\text { To explore GPs' views about treating } \\
\text { patients with obesity. }\end{array}$ & $\begin{array}{l}\text { General Practitioners } N=21 \\
\text { Age of general practitioners } N=9 \text { (aged } 30- \\
39 y r s) ~ N=5 \text { (aged } 40-49 y r s) ~ N=5 \text { (aged } 50-59 \\
\text { yrs) } N=2>60 \text { yrs } \\
\text { Gender } N=10 \text { male and } N=11 \text { females }\end{array}$ & $\begin{array}{l}\mathrm{N}=21 \text { In-depth semi- } \\
\text { structured interviews }\end{array}$ & $\begin{array}{l}\frac{\text { Interpretative }}{\text { Phenomenological }} \\
\frac{\text { Analysis }}{\text { (Smith \& Osborn, }} \\
\text { 2004) }\end{array}$ & $\begin{array}{l}\text { 1.Obesity is the } \\
\text { responsibility of the } \\
\text { patient and } 2 \text {. Patients see } \\
\text { obesity as a medical } \\
\text { problem and desire a } \\
\text { medical solution3. GPs lack } \\
\text { faith in treatment options } \\
\text { and desire good doctor- } \\
\text { patient relationship 4. } \\
\text { Due to the conflict GPs } \\
\text { sometimes offer } \\
\text { inappropriate treatments }\end{array}$ \\
\hline
\end{tabular}




\begin{tabular}{|c|c|c|c|c|c|c|}
\hline & & & & & & $\begin{array}{l}\text { and support for other } \\
\text { comorbidities. }\end{array}$ \\
\hline 6 & $\begin{array}{l}\text { Gudzune et al [29] } \\
\text { USA }\end{array}$ & $\begin{array}{l}\text { To explore PCPs' usual practices as } \\
\text { part of weight counseling to identify } \\
\text { how PCPs communicate with their } \\
\text { patients about weight loss. }\end{array}$ & $\begin{array}{l}\text { Physicians } \mathrm{N}=24 \\
\text { Nurse Practitioners } \mathrm{N}=2 \\
\text { Age }=\text { mean age }=46.4 \\
\text { Gender }=\mathrm{N}=15 \text { females and } \mathrm{N}=11 \text { males }\end{array}$ & $\mathrm{N}=5$ Focus groups & $\begin{array}{l}\text { Editing Analysis } \\
\text { Style } \\
\text { (Crabtree \& Miller, } \\
\text { 1992) }\end{array}$ & $\begin{array}{l}\text { 1.Motivating patients to } \\
\text { lose weight } \\
\text { 2. Partnering with the } \\
\text { patients to achieve weight } \\
\text { loss } 3 \text {. Handling challenges } \\
\text { that arise as part of weight } \\
\text { counselling }\end{array}$ \\
\hline 7 & $\begin{array}{l}\text { Gunther et al [70] } \\
\text { UK }\end{array}$ & $\begin{array}{l}\text { To uncover and describe barriers and } \\
\text { enablers to implementing NICE's } \\
\text { recommendations on the } \\
\text { management of obesity in adults in } \\
\text { general practice, using practical } \\
\text { qualitative methods. }\end{array}$ & $\begin{array}{l}\text { General Practitioners (GPs) } N=7 \\
\text { Practice Nurses } N=7 \\
\text { GPs } \\
\text { Age } N=4 \text { aged } 31-40, N=1 \text { aged } 41-50, N=2 \\
\text { aged } 51-60 \\
\text { Gender } N=4 \text { males, } N=3 \text { females } \\
\text { Practice Nurses } \\
\text { Age } N=2 \text { aged } 31-40, N=3 \text { aged } 41-50, N=1 \\
\text { aged } 45-64, N=1 \text { aged } 51-60 \\
\text { Gender } N=7 \text { females } \\
\text { Patients } N=9 \\
\text { Age } N=2 \text { aged } 20-30, N=1 \text { aged } 31-40, N=2 \\
\text { aged } 51-60, N=4 \text { aged } 61 \text { and over } \\
\text { Gender }=N=1 \text { male and } N=8 \text { females }\end{array}$ & $\begin{array}{l}\mathrm{N}=23 \text { semi-structured } \\
\text { interviews }\end{array}$ & $\begin{array}{l}\text { Thematic } \\
\text { Framework } \\
\text { Approach (Pope \& } \\
\text { Mays,1999) }\end{array}$ & $\begin{array}{l}\text { Patient: } \\
\text { 1. Motivation } \\
\text { 2. Patient Experience } \\
\text { 3. Stigma } \\
\text { 4. Cost of Services } \\
\text { Practitioner: } \\
\text { 1.Consultation with } \\
\text { patients 2. Consistency of } \\
\text { approach } \\
\text { 3. Not the practitioner's } \\
\text { responsibility }\end{array}$ \\
\hline 8 & $\begin{array}{l}\text { Hansson et al [40] } \\
\text { Sweden }\end{array}$ & $\begin{array}{l}\text { To describe how GPs and DNs, both } \\
\text { male and female, conceive their } \\
\text { encounters with obesity in primary } \\
\text { health care. }\end{array}$ & $\begin{array}{l}\text { General Practitioners (GPs) } \mathrm{N}=10 \\
\text { Age } \mathrm{N}=2 \text { aged } 34-40, \mathrm{~N}=2 \text { aged } 41-45, \mathrm{~N}=2 \\
\text { aged } 46-50, \mathrm{~N}=1 \text { aged } 51-55, \mathrm{~N}=3 \text { aged } 56- \\
60 \\
\text { Gender } \mathrm{N}=6 \text { female, } \mathrm{N}=4 \text { males } \\
\text { District Nurses ( } \mathrm{N}=10 \text { ) } \\
\text { Age } \mathrm{N}=1 \\
\text { Gender } \mathrm{N}=7 \text { female, } \mathrm{N}=3 \text { male }\end{array}$ & $\begin{array}{l}\mathrm{N}=20 \text { Semi-structured } \\
\text { interviews }\end{array}$ & $\begin{array}{l}\text { Phenomenographic } \\
\text { Approach } \\
\text { (Marton, 1981) }\end{array}$ & $\begin{array}{l}\text { 1: Adequate primary } \\
\text { health care } \\
\text { 2: promoting a healthy } \\
\text { lifestyle } \\
\text { 3: Need for competency } \\
\text { 4: Adherence to new } \\
\text { habits } \\
\text { 5: Understanding patient } \\
\text { attitudes }\end{array}$ \\
\hline 9 & $\begin{array}{l}\text { Heintze et al [71] } \\
\text { Germany }\end{array}$ & $\begin{array}{l}\text { This study analyses patients' and } \\
\text { physicians' visions for the future } \\
\text { management of obesity. }\end{array}$ & $\begin{array}{l}\text { General Practitioners (GPs) } \mathrm{N}=15 \\
\text { Age= mean age of } 51 \\
\text { Gender }=\mathrm{N}=6 \text { males and } \mathrm{N}=9 \text { females } \\
\text { Overweight patients } \mathrm{N}=15 \\
\text { Age= Age range between } 43-73 \text { yrs (mean } \\
\text { age } 59 \text { years) } \\
\text { Gender }=\mathrm{N}=4 \text { males and } \mathrm{N}=11 \text { females }\end{array}$ & $\begin{array}{l}\mathrm{N}=30 \text { in-depth semi- } \\
\text { structured interviews }\end{array}$ & $\begin{array}{l}\text { Qualitative Content } \\
\text { Analysis } \\
\text { (Mayring, 1983) }\end{array}$ & $\begin{array}{l}\text { 1: Weight loss goals and } \\
\text { motivation } \\
\text { 2: Dietary advice } \\
\text { 3: Physical activity } \\
\text { 4: Psychosocial aspects }\end{array}$ \\
\hline 10 & $\begin{array}{l}\text { Hong et al [72] } \\
\text { USA }\end{array}$ & $\begin{array}{l}\text { The aim of this qualitative study was } \\
\text { to assess family physicians' } \\
\text { understanding and perception of the } \\
\text { personal and environmental factors }\end{array}$ & $\begin{array}{l}\text { Family physicians } \mathrm{N}=35 \\
\text { Family Medicine Residents } \mathrm{N}=14\end{array}$ & $\mathrm{~N}=5$ Focus Groups & $\begin{array}{l}\text { Thematic Content } \\
\text { Analysis (Miles, } \\
\text { 1994) }\end{array}$ & $\begin{array}{l}\text { 1.Awareness \& practices } \\
\text { of counselling related to } \\
\text { PA/walking } \\
\text { 2. Physicians' reactions to }\end{array}$ \\
\hline
\end{tabular}




\begin{tabular}{|c|c|c|c|c|c|c|}
\hline & & $\begin{array}{l}\text { influencing PA, especially walking, } \\
\text { and factors affecting their counseling } \\
\text { of obese patients about } \\
\text { environmental motivators and } \\
\text { barriers to PA. }\end{array}$ & & & & $\begin{array}{l}\text { patients' inactivity. } \\
\text { 3.Understanding of the } \\
\text { relationship between } \\
\text { neighbourhood } \\
\text { environments \& PA } \\
\text { 4. Physicians' attitudes } \\
\text { toward environmental } \\
\text { resources to promote } \\
\text { PA/walking }\end{array}$ \\
\hline 11 & $\begin{array}{l}\text { Kim et al [114] } \\
\text { Australia }\end{array}$ & $\begin{array}{l}\text { To describe the factors influencing } \\
\text { general practitioners' (GPs) referral } \\
\text { intentions for their obese patients. }\end{array}$ & General Practitioners N=24 & $\begin{array}{l}\mathrm{N}=24 \text { semi-structured } \\
\text { interviews }\end{array}$ & $\begin{array}{l}\text { Inductive thematic } \\
\text { analysis }\end{array}$ & $\begin{array}{l}\text { GPs' own attitudes, } \\
\text { experience and options. } \\
\text { 2.Patient's motivation } \\
\text { 3. GPs' previous } \\
\text { experience } \\
\text { 4.Patients' expectations }\end{array}$ \\
\hline 12 & $\begin{array}{l}\text { Leverence et al } \\
\text { [73] } \\
\text { USA }\end{array}$ & $\begin{array}{l}\text { To examine the views of clinicians on } \\
\text { obesity counseling and to compare } \\
\text { these views to the recommendations } \\
\text { of leading obesity guidelines. }\end{array}$ & $\begin{array}{l}\text { For the in-depth interviews } \\
\text { Family Physicians \& Internists } \mathrm{N}=8 \\
\text { Pediatricians } \mathrm{N}=5 \\
\text { Mid-level practitioners } \mathrm{N}=7 \\
\text { Age = not stated } \\
\text { Gender } \mathrm{N}=11 \text { males, } \mathrm{N}=9 \text { females } \\
\text { For the focus groups } \\
\text { Family Physicians \& Internists } \mathrm{N}=6 \\
\text { Pediatricians } \mathrm{N}=2 \\
\text { Mid-level practitioners } \mathrm{N}=2 \\
\text { Age = not stated } \\
\text { Gender } \mathrm{N}=6 \text { males, } \mathrm{N}=4 \text { males }\end{array}$ & $\begin{array}{l}\mathrm{N}=20 \text { in-depth } \\
\text { interviews and } \mathrm{N}=10 \\
\text { focus group subjects }\end{array}$ & $\begin{array}{l}\text { Immersion/crystalliz } \\
\text { ation and template } \\
\text { approaches }\end{array}$ & $\begin{array}{l}\text { 1.Screening and } \\
\text { Counselling } \\
\text { 2.Resources to support } \\
\text { weight loss } \\
\text { 3.Patient motivation } \\
\text { 4. Cultural context } \\
\text { 5. Community and family } \\
\text { context } \\
\text { 6. Effectiveness of } \\
\text { treatment }\end{array}$ \\
\hline 13 & $\begin{array}{l}\text { Mercer \& Tessier } \\
\text { [74] } \\
\text { UK }\end{array}$ & $\begin{array}{l}\text { To examine general practitioners' } \\
\text { and practice nurses' perceptions of } \\
\text { obesity, their strategies and attitudes } \\
\text { towards weight management, and } \\
\text { their views on the major obstacles to } \\
\text { (and need for) better weight } \\
\text { management in primary care. }\end{array}$ & $\begin{array}{l}\text { General Practitioners (GPs) } \mathrm{N}=10 \\
\text { Age }=\text { all below the age of } 55 \\
\text { Gender } \mathrm{N}=7 \text { females and } \mathrm{N}=3 \text { males } \\
\text { Practice Nurses (PNs) } \mathrm{N}=10 \\
\text { Age=all below the age of } 55 \\
\text { Gender } \mathrm{N}=10 \text { females }\end{array}$ & $\begin{array}{l}\mathrm{N}=20 \text { Semi-structured } \\
\text { interviews }\end{array}$ & Not stipulated & $\begin{array}{l}\text { 1.GPs and PNs had little } \\
\text { enthusiasm for weight } \\
\text { management. } \\
\text { 2.GPs-not appropriate use } \\
\text { of time } \\
\text { 3. Frustrated at lack of } \\
\text { success } \\
\text { 4.Patients lack motivation } \\
\text { 5. GPs keener to tackle } \\
\text { obesity when patient had } \\
\text { comorbidities }\end{array}$ \\
\hline 14 & $\begin{array}{l}\text { Schauer et al } \\
\text { [115] } \\
\text { USA }\end{array}$ & $\begin{array}{l}\text { To explore how clinicians approach } \\
\text { weight counseling, including who } \\
\text { they counsel, how they bring up } \\
\text { weight, what advice they provide, } \\
\text { and what treatment referral } \\
\text { resources they use. }\end{array}$ & $\begin{array}{l}\text { Primary Care Physicians } \mathrm{N}=30 \\
\text { Physicians } \mathrm{N}=14 \\
\text { Physician Assistants } \mathrm{N}=11 \\
\text { Nurse Practitioners } \mathrm{N}=5 \\
\text { Age } \\
\mathrm{N}=6 \text { (aged between } 18-35 \text { ) } \mathrm{N}=13 \text { (aged } \\
\text { between } 36-45 \text { ) } \\
\mathrm{N}=3 \text { (aged between } 46-55 \text { ) } \\
\mathrm{N}=8 \text { (aged between } 56-65 \text { ) }\end{array}$ & $\begin{array}{l}\mathrm{N}=30 \text { Semi -structured } \\
\text { interviews }\end{array}$ & Not stipulated & $\begin{array}{l}\text { 1. When and to whom } \\
\text { clinicians counsel about } \\
\text { weight } 2 \text {. How clinicians } \\
\text { bring up the topic of } \\
\text { weight with patients } 3 \text {. } \\
\text { What do clinicians say to } \\
\text { patients about their } \\
\text { weight } 4 \text {. Dietary advice } 5 \text {. } \\
\text { Physical activity advice } 6 \text {. }\end{array}$ \\
\hline
\end{tabular}




\begin{tabular}{|c|c|c|c|c|c|c|}
\hline & & & $\begin{array}{l}\text { Gender } \\
N=16 \text { female } \\
N=14 \text { male }\end{array}$ & & & $\begin{array}{l}\text { Advice specifically about } \\
\text { weight loss } 7 \text {. What } \\
\text { treatment resources do } \\
\text { clinicians offer patients for } \\
\text { weight loss? 8. Basing } \\
\text { advice \& treatment on } \\
\text { personal experience. } \\
\end{array}$ \\
\hline 15 & $\begin{array}{l}\text { Sonntag et al [75] } \\
\text { USA }\end{array}$ & $\begin{array}{l}\text { Identifying GPs' perspectives on } \\
\text { counselling overweight and obese } \\
\text { patients. }\end{array}$ & $\begin{array}{l}\text { Primary Care Physicians (GPs) } \mathrm{N}=15 \\
\text { Age mean age }=51 \text { years } \\
\text { Gender } \mathrm{N}=6 \text { male } \mathrm{N}=9 \text { female }\end{array}$ & $\begin{array}{l}\text { Semi-structured } \\
\text { guided interview }\end{array}$ & $\begin{array}{l}\text { Qualitative Content } \\
\text { Analysis }\end{array}$ & $\begin{array}{l}\text { 1. GP's role in obesity } \\
\text { therapy } 2 . \text { Need to treat } \\
\text { 3.Situations in which the } \\
\text { topic of overweight is } \\
\text { addressed4. GP's } \\
\text { objectives in obesity } \\
\text { treatment } 5 \text {. Barriers to } \\
\text { obesity treatment }\end{array}$ \\
\hline 16 & $\begin{array}{l}\text { Teixeira et al } \\
{[116]} \\
\text { Portugal }\end{array}$ & $\begin{array}{l}\text { To understand GPs' views about } \\
\text { obesity and obese people and how } \\
\text { these professionals perceive their } \\
\text { role in the treatment of this disease. }\end{array}$ & $\begin{array}{l}\text { General Practitioners (GPs) } \mathrm{N}=16 \\
\text { Age }=\text { all between } 32 \text { and } 57 \text { years } \\
\text { Mean age = } 51 \text { years } \\
\text { Gender } \\
N=7 \text { male } \\
N=9 \text { female }\end{array}$ & $\begin{array}{l}\mathrm{N}=16 \text { semi structured } \\
\text { interviews }\end{array}$ & Thematic Analysis & $\begin{array}{l}\text { 1.Obesity as a public } \\
\text { health concern } 2 \text {. Obese } \\
\text { characteristics } v \text { treatment } \\
\text { demands } 3 \text {. GPs' sense of } \\
\text { defeat vs need to treat. }\end{array}$ \\
\hline
\end{tabular}


Figure 1: PRISMA Flow chart detailing the process of study identification

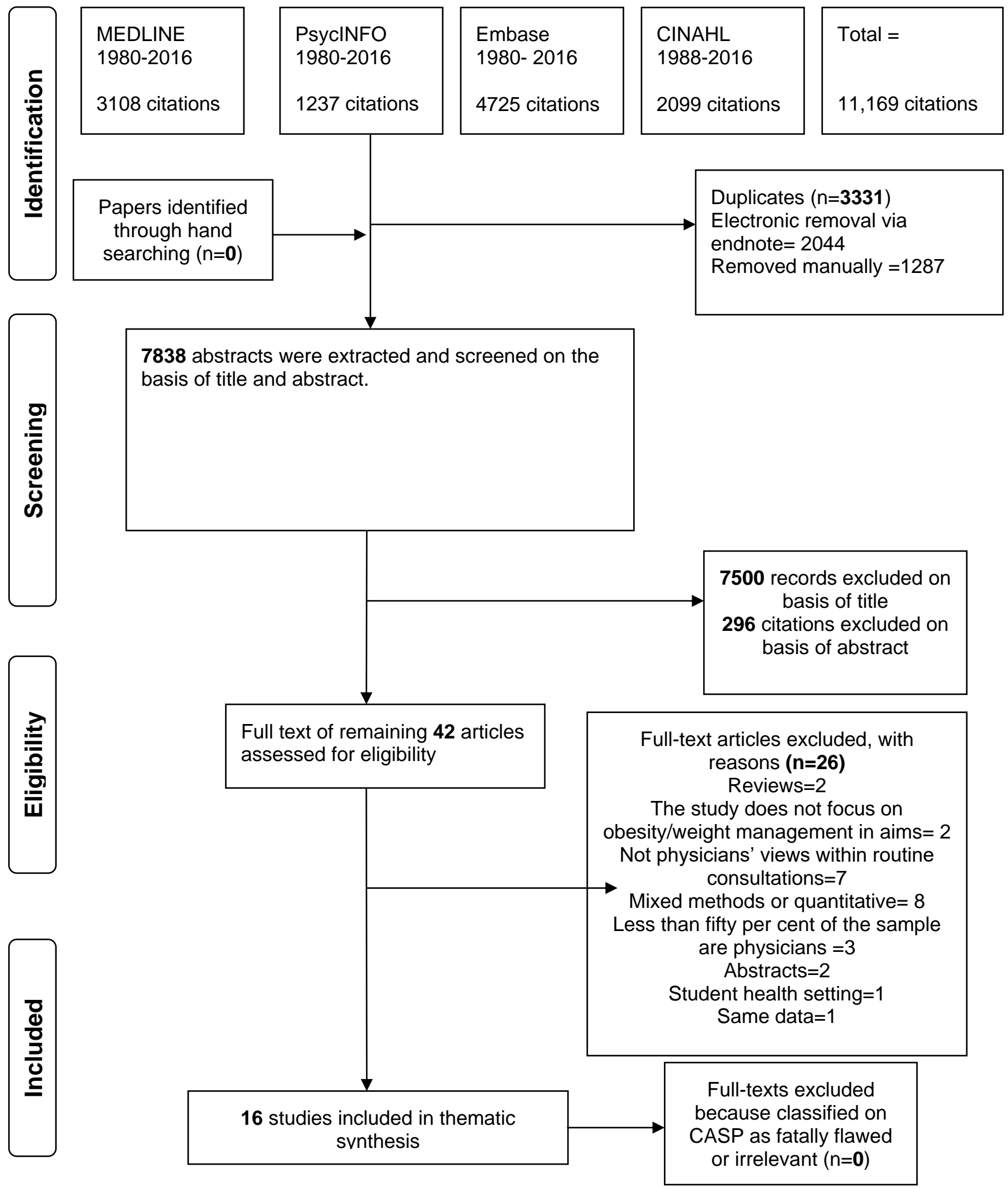


Figure 2. Physicians' experiences of discussing weight management within a routine consultation: analytical and descriptive themes 


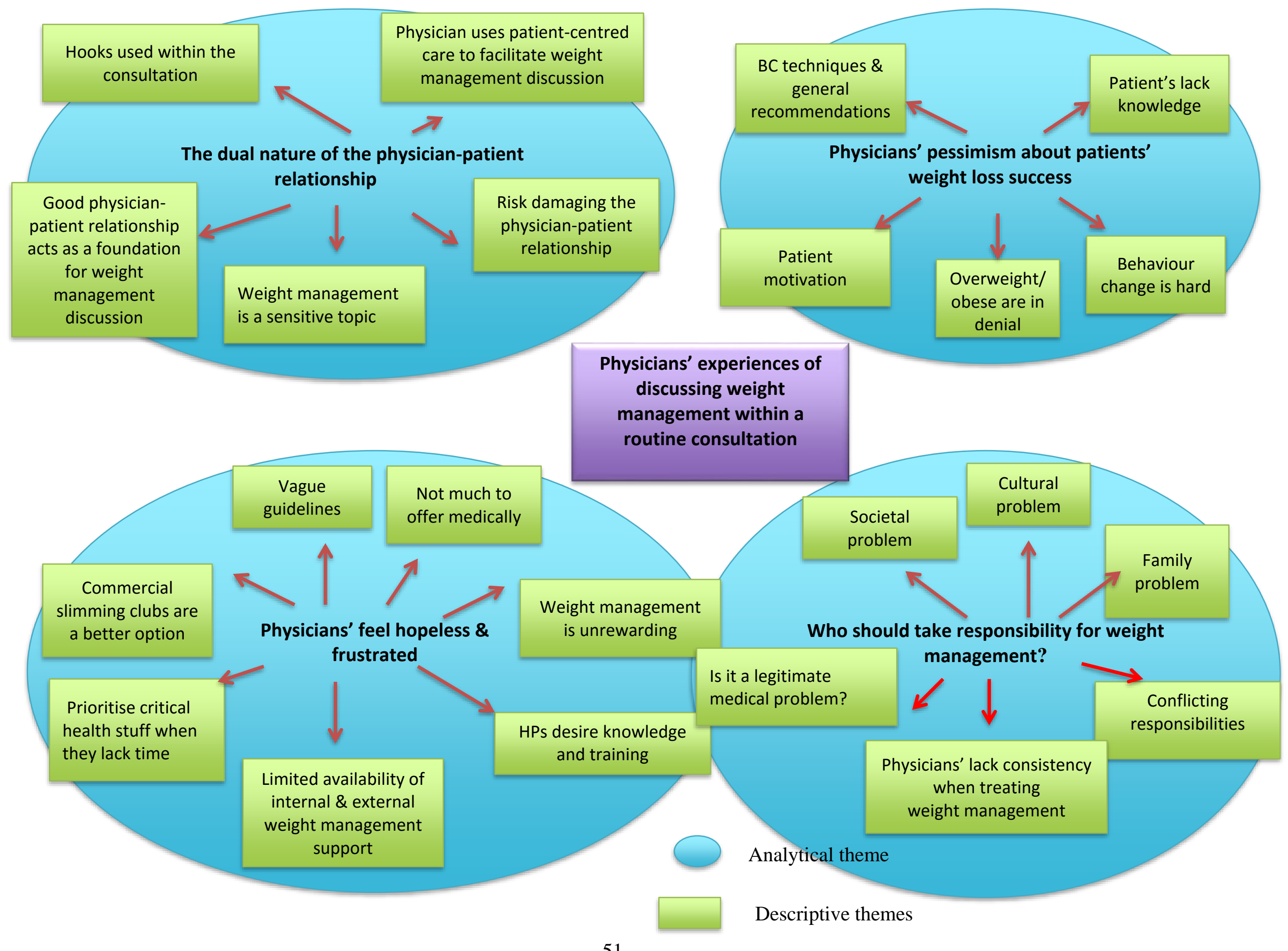




\section{Text Box 1}

Text Box 1. Additional quotations to demonstrate analytical themes

\section{Physicians' pessimism about patients' weight loss success}

"On the whole I'd say the success rate is quite low, in terms of major changes" Kim et al 2015 [Urban GP \#2]

"I want lots of people with a BMI over 30 to go somewhere, but most are not really interested or motivated to change" Kim et al 2015 [Rural GP $\# 1]$

\section{Physicians' feel hopeless and frustrated}

"PCPs avoided discussing weight and weight loss entirely when trying to balance multiple priorities during the patient visit. PCPs avoided discussing weight and instead focused on the patients' co-morbidities: "Most of these people do have co-morbidities, and those co-morbidities often overwhelm the visit" Gudzune (2012) [author interpretation]

"Many of the GPs and PNs interviewed expressed a keen interest in having a dietician attached to the practice, to advise on difficult or complex cases and to help support the efforts of the PNs" Mercer \& Tessier (2001) [author interpretation]

\section{The dual nature of the physician-patient relationship}

"Living in this state of conflict was particularly uncomfortable for many doctors as they felt that it presented a challenge to their relationship with their obese patients and believed that a good relationship with their patients was central to their role as a GP” Epstein \& Ogden (2005) [Author interpretation]

"You just find that you 'hit' someone at precisely the right moment and something you say, or something you enable patients to think about can change... change their life quite dramatically". Claridge et al 2014 (GP 8)

"People seem to be quite accepting of me talking about weight, whereas in other social settings you could never discuss someone's weight". Claridge et al 2014 (GP 4)

\section{Who should take responsibility for weight management}

"Physicians consider that obese patients want that doctors hold control and responsibility over the treatment, don't recognize the nature, consequences and gravity of the problem and deny their condition, lacking commitment" Teixeira et al 2015 [author interpretation]

"Some women think healthy food is not interesting," while some felt that Emirati women accept their higher body weight, hindering promotion of weight loss during counseling" Ali (2009) [author interpretation] 